\title{
Relationship between Plasma Adiponectin Level and Peptic Ulcer Disease
}

\author{
SALLY A. EL-SHANWANY, M.Sc., M.B.B.Ch.*; HEBA A. MOURAD, M.D.**; \\ MOHAMED A. EL-SEBAEY, M.D.* and WALEED S. MOHAMED, M.D.* \\ The Departments of Internal Medicine* and Clinical Pathology**, Faculty of Medicine, Tanta University
}

\begin{abstract}
Background: Adipose tissue is an endocrine organ that secretes various bioactive adipocytokines, such as adiponectin. Adiponectin has anti-inflammatory, anti-diabetic and antiatherosclerotic properties. Therefore, it may act as a protector against multiple metabolic disorders, including diabetes mellitus, dyslipidemia, and hypertension. In addition, it may have a relationship with some gastrointestinal disorders, such as gastro-esophageal reflux disease, gastritis and peptic ulcer disease.
\end{abstract}

Aim of Study: Aim of the work: The main contribution of this work is to determine the relation between plasma adiponectin level and peptic ulcer disease which was diagnosed previously by endoscopy.

Subjects and Methods: This study was carried out on 60 patients and 20 healthy control individuals, who were subjected to full history taking, thorough clinical examination and Body Mass Index (BMI) measurement. Laboratory investigations were carried out including Fasting Blood Glucose (FBG), Complete Blood Count (CBC), liver function tests, renal function tests, helicobacter pylori antigen in stool, serum triglyceride, serum cholesterol and serum adiponectin level. Upper GIT endoscopy was used for screening the individuals to diagnose gastritis or ulcer.

Results: A negative correlation was established between endoscopically diagnosed patients with Peptic Ulcer Disease (PUD) and gastritis and plasma adiponectin level.

Conclusion: Patients with peptic ulcer disease and gastritis had low plasma adiponectin level.

Key Words: Adiponectin-Endoscopy-Gastritis - Peptic ulcer.

\section{Introduction}

PEPTIC Ulcer Disease (PUD) is one of the most common gastrointestinal diseases that affect approximately 4.5 million people annually. $10 \%$ $20 \%$ of patients with PUD will experience complications. In Egypt, the incidence of PUD is approx-

Correspondence to: Dr. Waleed S. Mohamed, E-Mail:wsmohamed1@yahoo.com imately $8.1 \%$ per year, $6 \%$ men and $2.1 \%$ women. The Egyptian annual mortality rate is $4-6$ people per 100,000 cases $[\mathbf{1 , 2}]$. PUD is a multifactorial disease based on etiology and risk factors. Ulcers occur with hyper-secretion of hydrochloric acid and pepsin that cause an imbalance between gastric luminal factors and degradation in the defensive function of the gastric mucosal barrier.

When acid and pepsin invade a weakened area of the mucosal barrier, histamine is released which will stimulate parietal cells to secrete more acid. Erosion occurs to form the ulcer with the continuation of this vicious cycle [3]. Ulcer bleeding, perforation, pyloric obstruction and gastric malignancy are the most common complications of PUD. Bleeding PUD represents about $60 \%$ of the causes of upper Gastrointestinal (GI) bleeding. It is the second common cause of upper GI bleeding in Egypt. The mortality rate due to ulcer hemorrhage is approximately $5 \%$ [4].

Adiponectin is one of the bioactive proteins, which are secreted by the adipose tissue. Production and secretion of adipocytokines are regulated mainly by the nutritional condition and lifestyle factors such as physical inactivity. Adiponectin is adipocyte specific cDNA encoding a 244-amino-acid protein, that is homologous to collagen VIII and X and complement factor C1q. Adiponectin is the most abundant gene product in adipose tissue and accounts for $0.01 \%$ of total plasma protein [5] . Recently, it was demonstrated that adiponectin inhibited TNF- $a$ induced expression of endothelial adhesion molecules. Experimental studies demonstrated that adiponectin expression is negatively regulated by pro-inflammatory cytokines including IL-6 and TNF-a, whereas adiponectin modulates the action and production of TNF- $a$ in various tissues [6]. 
Accordingly, several studies shown that hypoadiponectinemia is associated with increased IL-6 [7]. Adiponectin is inversely correlated to body fat percentage, central fat distribution, fasting plasma insulin, abnormal oral glucose tolerance as it plays a role in fatty acid catabolism [8]. Hypoadiponectinemia was noticed with certain diseases, including diabetes mellitus, hyperlipidemia, hypertension, atherosclerosis, and coronary heart disease [9]. The role of adiponectin in PUD according to its protective and anti-inflammatory properties up to our knowledge is not clear. Hence, the aim of this work is to determine the relation between plasma adiponectin level and PUI diagnosed by endoscopy.

\section{Subjects and Methods}

This cross sectional study was carried out on 60 patients and 20 healthy persons from Gastroenterology and Hepatology Unit (inpatient and outpatient), Internal Medicine Department, Tanta University Hospital from June 2017 to May 2018. The study was approved by the Faculty Ethical Committee; informed consent of the patient was obtained.

The study population was classified into three groups:

- Group 1: Includes 30 patients endoscopically diagnosed with gastritis.

- Group 2: Includes 30 patients endoscopically diagnosed with peptic ulcer.

- Group 3: (control group): Includes 20 apparently healthy persons who were endoscopically diagnosed free of neither gastritis nor peptic ulcer.

\section{Inclusion criteria:}

Patients of different ages and sex presented with endoscopically diagnosed peptic ulcer or gastritis were enrolled in this study.

\section{Exclusion criteria:}

Patients with diabetes mellitus, dyslipidemia, hypertension, ischemic heart disease, patients using NSAID for last 3 month and patients with body mass index more than 30 .

\section{All subjects were subjected to the following:}

History taking: Regarding age, sex and special habits (smoking and alcohol).

Thorough clinical examination: Including, vital signs, chest, cardiac and abdominal examination, Body Mass Index (BMI) was measured by the equation (weight by $\mathrm{kg}$ ) $/\left(\right.$ height $/ \mathrm{m}^{2}$ ) [10]
Laboratory investigations: Morning samples were collected from antecubital vein after an overnight fast under complete aseptic technique: Fasting Blood Glucose (FBG), Complete Blood Count (CBC), liver function tests: Total and direct bilirubin, SGOT, SGPT, serum albumin, prothrombin time and activity, renal function tests (blood urea and serum creatinine), helicobacter pylori antigen in stool, serum triglyceride and cholesterol and serum adiponectin level.

Pelvi-abdominal ultrasonography: Was used to detect any pelvi-abdominal organ disease. Upper GIT endoscopy: Upper gastrointestinal endoscopy screening was done to diagnose gastric mucosal defects such as gastritis or ulcer (gastric and duodenal).

\section{Statistical analysis of the data:}

Data entry and statistical analyses were performed using SPSS [statistical package of social sciences) Version 20 (Armonk, NY: IBM Corp). Data were expressed in mean and standard deviation. Categorical data were expressed in numbers and percentage. The quantitative data were examined by Kolmogorov Smirnov test for normality of data. Chi square test was used to compare categorical data. Independent sample $t$-test (student $t$ test) was used for continuous normally distributed data. Analysis of Variance (ANOVA) test was used for multivariate continuous normally distributed data. Statistical significance was considered when probability $(p)$ value was less than 0.05 .

\section{Results}

There was no statistically significant difference between the three studied groups regarding gender, age, smoker, ex-smoker or nonsmokers. All participants involved in the study were nonalcoholic. There was no statistically significant difference between the studied groups as regard age, BMI, SBP or DBP (Tables 1,2).

No statistically significant difference was detected between the studied groups as regard patient's complaint (abdominal pain, dyspepsia, vomiting) with a statistically significant difference between group 1 and group 2 as regard upper GIT bleeding (Table 3).

There was a statistically significant difference between the three groups as regard hemoglobin level, serum cholesterol level and the international normalized ratio with no statistically significant difference as regard serum creatinine, fasting blood sugar, or triglyceride level. There was a statistically significant difference between the peptic ulcer and 
control group as regard $\mathrm{Hb}$ and serum cholesterol level and between gastritis group and control group (Table 4).

There was no statistically significant difference between the groups as regard $\mathrm{H}$. pylori infection (Table 5).

In peptic ulcer group, the adiponectin level was low in $83.3 \%$, normal in $16.7 \%$ the mean was 2.99 \pm 2.63 . In the control group, the adiponectin was low in $30 \%$, normal in $70 \%$ and the mean was 8.43 \pm 7.41 . There was a statistically significant difference between gastritis group and control group also, between peptic ulcer and control group. Lower levels of adiponectin were detected in gastritis and peptic ulcer groups compared to control group (Table 6).

There was a significant negative correlation between serum cholesterol level and adiponectin level in group 1 ( $p=0.037$ ) Fig. (1).

Our results revealed a negative correlation between peptic ulcer and gastritis and plasma adiponectin level as in gastritis and peptic ulcer groups, the adiponectin level was low in $76.7 \%$, normal in $23.3 \%$ and the mean was $3.0 \pm 2.40 .9$ Fig. (2).

Table (1): Comparison between the studied groups as regard gender and smoking.

\begin{tabular}{|c|c|c|c|c|c|c|c|}
\hline & \multicolumn{2}{|c|}{$\begin{array}{c}\text { Gastritis } \\
(\mathrm{N}=30)\end{array}$} & \multicolumn{2}{|c|}{$\begin{array}{l}\text { Peptic ulcer } \\
\quad(\mathrm{N}=30)\end{array}$} & \multicolumn{2}{|c|}{$\begin{array}{l}\text { Control } \\
(\mathrm{N}=20)\end{array}$} & \multirow{2}{*}{$p$} \\
\hline & No. & $\%$ & No. & $\%$ & No. & $\%$ & \\
\hline \multicolumn{8}{|l|}{ Gender: } \\
\hline Male & 14 & 46.7 & 17 & 56.7 & 8 & 40.0 & 0.492 \\
\hline Female & 16 & 53.3 & 13 & 43.3 & 12 & 60.0 & \\
\hline \multicolumn{8}{|l|}{ Smoking: } \\
\hline Non-smoker & 23 & 76.7 & 21 & 70.0 & 18 & 90.0 & 0.476 \\
\hline Smoker & 5 & 16.7 & 8 & 26.7 & 2 & 10.0 & \\
\hline Ex-smoker & 2 & 6.7 & 1 & 3.3 & 0 & 0.0 & \\
\hline
\end{tabular}

Table (2): Comparison between the studied groups as regard age, BMI, SBP and DBP.

\begin{tabular}{|c|c|c|c|c|c|c|c|}
\hline & \multicolumn{2}{|c|}{$\begin{array}{c}\text { Gastritis } \\
(\mathrm{N}=30)\end{array}$} & \multicolumn{2}{|c|}{$\begin{array}{l}\text { Peptic ulcer } \\
\quad(\mathrm{N}=30)\end{array}$} & \multicolumn{2}{|c|}{$\begin{array}{l}\text { Control } \\
(\mathrm{N}=20)\end{array}$} & \multirow{2}{*}{$p$} \\
\hline & M & SD & M & SD & M & SD & \\
\hline Age (years) & 51.93 & 13.21 & 50.80 & 16.14 & 42.0 & 16.63 & 0.062 \\
\hline BMI $\left(\mathrm{kg} / \mathrm{m}^{2}\right)$ & 26.33 & 2.19 & 25.17 & 2.34 & 25.25 & 1.48 & 0.070 \\
\hline $\mathrm{SBP}(\mathrm{mmHg})$ & 119.0 & 17.29 & 118.7 & 17.76 & 111.0 & 10.21 & 0.173 \\
\hline DBP (mmHg) & 79.67 & 8.50 & 76.67 & 10.93 & 74.50 & 6.86 & 0.141 \\
\hline
\end{tabular}

ANOVA test.

*: Statistically significant at $p<0.05$.
Table (3): Comparison between the three studied groups according to patient's complaint.

\begin{tabular}{|c|c|c|c|c|c|c|c|}
\hline \multirow[t]{2}{*}{ Complaint } & \multicolumn{2}{|c|}{$\begin{array}{c}\text { Gastritis } \\
(\mathrm{N}=30)\end{array}$} & \multicolumn{2}{|c|}{$\begin{array}{l}\text { Peptic ulcer } \\
\qquad(\mathrm{N}=30)\end{array}$} & \multicolumn{2}{|c|}{$\begin{array}{l}\text { Control } \\
(\mathrm{N}=20)\end{array}$} & \multirow{2}{*}{$p$} \\
\hline & No. & $\%$ & No. & $\%$ & No. & $\%$ & \\
\hline Abdominal pain & 5 & 16.6 & 10 & 33.3 & 6 & 20.0 & 1.000 \\
\hline Bleeding & 8 & 26.6 & 7 & 23.3 & 0 & 0.0 & $0.010^{*}$ \\
\hline Dyspepsia & 8 & 26.6 & 6 & 20.0 & 5 & 25.0 & 0.292 \\
\hline Pallor & 4 & 13.3 & 3 & 10.0 & 4 & 20.0 & 0.630 \\
\hline Vomiting & 5 & 16.6 & 4 & 13.3 & 5 & 25.0 & 1.000 \\
\hline
\end{tabular}

*: Statistically significant at $p<0.05$.

Table (4): Comparison between the three studied groups according to laboratory investigations.

\begin{tabular}{|c|c|c|c|c|}
\hline \multirow{2}{*}{$\begin{array}{l}\text { Laboratory } \\
\text { investigation }\end{array}$} & $\begin{array}{c}\text { Gastritis } \\
(\mathrm{N}=30)\end{array}$ & $\begin{array}{l}\text { Peptic ulcer } \\
(\mathrm{N}=30)\end{array}$ & $\begin{array}{l}\text { Control } \\
(\mathrm{N}=20)\end{array}$ & \multirow[t]{2}{*}{$p$} \\
\hline & M SD & M SD & M SD & \\
\hline • $\mathrm{Hb}(\mathrm{g} / \mathrm{dl})$ & \multicolumn{3}{|c|}{$p 1=0.500, p 2=0.208, p 3=0.022 *$} & $0.029 *$ \\
\hline - $\mathrm{TG}(\mathrm{mg} / \mathrm{dl})$ & $170.5 \pm 45.33$ & $176.8 \pm 43.78$ & $149.1 \pm 33.97$ & 0.072 \\
\hline $\begin{array}{l}\text { - Cholesterol } \\
(\mathrm{mg} / \mathrm{dl})\end{array}$ & \multicolumn{3}{|c|}{$p 1=0.991, p 2=0.011 *, p \underline{3}=0.008 *$} & $0.005^{*}$ \\
\hline - INR & $\begin{array}{l}1.17 \pm 0.27 \\
p 1=0.401\end{array}$ & $\begin{array}{c}1.11 \pm 0.23 \\
1, p 2=0.012^{*},\end{array}$ & $\begin{array}{l}1.02 \pm 0.04 \\
3=0.079\end{array}$ & $0.041 *$ \\
\hline $\begin{array}{l}\text { - S. creatinine } \\
(\mathrm{mg} / \mathrm{dl})\end{array}$ & $1.50 \pm 1.46$ & $1.48 \pm 1.84$ & $0.96 \pm 0.26$ & 0.252 \\
\hline - FBS (mg/dl) & $94.27 \pm 23.29$ & $90.43 \pm 15.03$ & $87.55 \pm 18.03$ & 0.468 \\
\hline
\end{tabular}

$p$ : Value for comparing between the three groups.

$p 1$ : Value for comparing between group 1 and group 2 . p2: Value for comparing between group 1 and group 3 .

$p_{3}$ : Value for comparing between group 2 and group 3 .

: Statistically significant at $p<0.05$.

Table (5): Comparison between the three studied groups according to $\mathrm{H}$. pylori.

\begin{tabular}{|c|c|c|c|c|c|c|c|}
\hline \multirow{2}{*}{ H.pylori } & \multicolumn{2}{|c|}{$\begin{array}{l}\text { Gastritis } \\
(\mathrm{N}=30)\end{array}$} & \multicolumn{2}{|c|}{$\begin{array}{l}\text { Peptic ulcer } \\
\quad(\mathrm{N}=30)\end{array}$} & \multicolumn{2}{|c|}{$\begin{array}{l}\text { Control } \\
(\mathrm{N}=20)\end{array}$} & \multirow{2}{*}{$p$} \\
\hline & No. & $\%$ & No. & $\%$ & No. & $\%$ & \\
\hline Negative & 28 & 93.3 & 26 & 86.7 & 18 & 90.0 & 0.894 \\
\hline Positive & 2 & 6.7 & 4 & 13.3 & 2 & 10.0 & \\
\hline
\end{tabular}

Table (6): Comparison between the three studied groups according to adiponectin.

\begin{tabular}{|c|c|c|c|c|c|c|}
\hline \multirow{2}{*}{$\begin{array}{l}\text { Adiponectin } \\
(\mu \mathrm{g} / \mathrm{ml})\end{array}$} & \multirow{2}{*}{$\begin{array}{c}\begin{array}{c}\text { Gastritis } \\
(\mathrm{N}=30)\end{array} \\
\text { No. \% }\end{array}$} & \multicolumn{2}{|c|}{$\begin{array}{l}\text { Peptic ulcer } \\
\qquad(\mathrm{N}=30)\end{array}$} & \multicolumn{2}{|c|}{$\begin{array}{l}\text { Control } \\
(\mathrm{N}=20)\end{array}$} & \multirow[t]{2}{*}{$p$} \\
\hline & & No. & $\%$ & No. & $\%$ & \\
\hline Low & 76.7 & 25 & 83.3 & 6 & 30.0 & $<0.001 *$ \\
\hline Normal & 23.3 & 5 & 16.7 & 14 & 70.0 & \\
\hline High & $0 \quad 0.0$ & & 0.0 & 0 & 0.0 & \\
\hline \multirow[t]{2}{*}{ Mean $\pm \mathrm{SD}$} & $3.0 \pm 2.40$ & \multicolumn{2}{|c|}{$2.99 \pm 2.63$} & \multicolumn{2}{|c|}{$8.43 \pm 7.41$} & $<0.001 *$ \\
\hline & \multicolumn{5}{|c|}{$p 1=0.837, p 2<0.001 *, p 3<0.001 *$} & \\
\hline
\end{tabular}

$\chi^{2}$ : Chi-square test. ANOVA test.

$p$ : Value for comparing between the three groups.

p1: Value for comparing between group 1 and group 2.

p2: Value for comparing between group 1 and group 3.

p3: Value for comparing between group 2 and group 3 .

Statistically significant at $p<0.05$. 


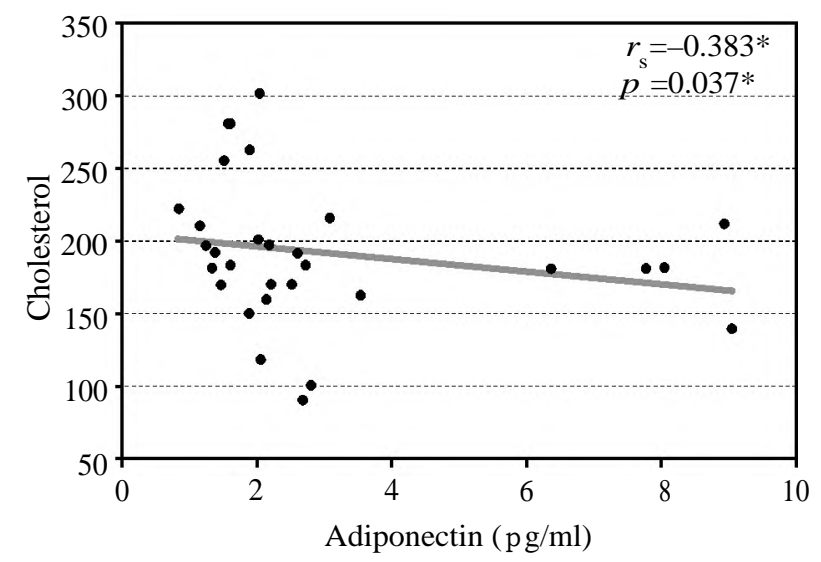

Fig. (1): Diagram showed a significant negative correlation between serum cholesterol level and adiponectin $(\mathrm{pg} / \mathrm{ml})$ level in group 1 .

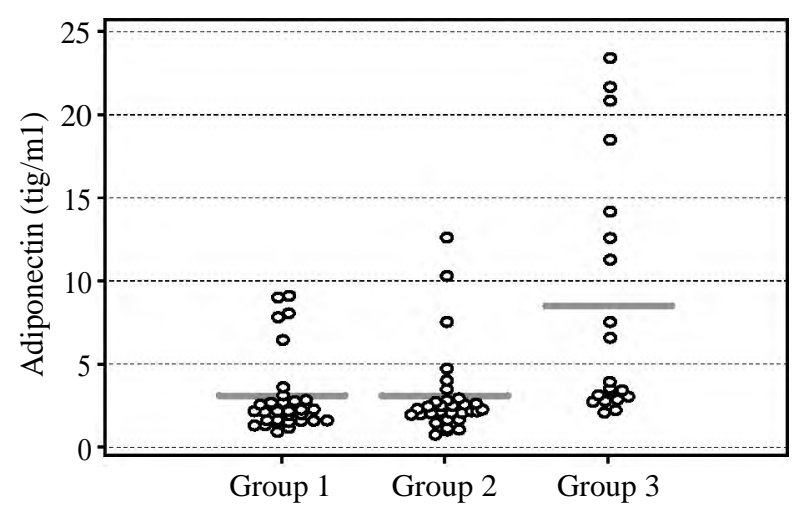

Fig. (2): The diagram showed that the adiponectin level distribution was lower in both gastritis and peptic ulcer groups compared to control group.

\section{Discussion}

In this study, females represent $51.25 \%$ of the participants while males represent $48.75 \%$ with no significant difference between both sexes regarding serum adiponectin level. Scherer et al., [11] explained that, the effect of sex difference on adiponectin level was established during neonatal imprinting of adipocyte or brain function by androgens independent from adult sex hormone regulation. Bottner et al., [12] have proposed that the sex difference is established at puberty; adiponectin levels decrease in boys with increasing testosterone levels and are unchanged in girls. Laughlin et al., [13] demonstrated that endogenous sex hormones did not explain the higher circulating adiponectin levels in women than men.

In our work, the range of age was between 2180 years for gastritis group, 21-85 years for peptic ulcer group and 18-68 years for the control group with no significant difference between serum adiponectin level and age in gastritis and peptic ulcer patients. In contrary to our results, Obata et al., [14] found that serum adiponectin level has a positive correlation with age in both sex. The levels are increased in elderly ( $<60$ years) and significantly lower in young healthy subjects ( $<40$ years). Cnop et al., [15] also reported higher adiponectin levels at older ages in healthy men and women between the ages of 32-75 years irrespective to sex difference.

Cohen et al., revealed that serum adiponectin level increased about 1 ond for every 10 years of age in healthy subjects but the pathogenesis of this correlation was unclear. In the present study, there was no significant difference between the three groups as regard BMI. On contrary to our results: Cohen $S$ et al., [16] demonstrated that with larger numbers of women with higher values of BMI showed a decrease in adiponectin. Combs et al., [17] as well showed that adiponectin was lower among overweight and obese women compared to average weight women. In our study, most of the participants had nearly normal systolic and diastolic blood pressure. On the other hand, Baden $\mathrm{M}$ et al., [18] documented that there was a negative relation between BP and adiponectin level in healthy people. Adamczak et al., [19] as well reported that plasma adiponectin levels were significantly lower in essential hypertensive patients compared with normotensive subjects. Iwashima et al., [20] also reported that hypoadiponectinaemia is a risk factor and predictor for hypertension.

All study participants were not consuming alcohol. Sierksma, et al., [21] concluded that consumption of at least one alcoholic beverage daily was associated with 7-15\% higher adiponectin levels. Steven, et al., [22] showed that higher adiponectin level could be detected in women consuming alcohol than in men, the majority of participants in the study are non-smokers $77.5 \%$ with no significant difference in the adiponectin level in smoker group in comparison with nonsmoker ones. In agreement with our results, Jaw-Shiun, et al., [23] reported that adiponectin levels did not vary by smoking status. In contrary to that, Kotani $\mathrm{K}$, et al., [24] found lower adiponectin level in current smokers relative to non-smokers and smoking cessation could increase adiponectin level.

We found that, no significant difference in adiponectin level between $\mathrm{H}$. pylori negative and positive patients. Ando et al., [25] showed that, there was no statistically significant difference in adiponectin level between $\mathrm{H}$. pylori positive and negative patients. Torisu et al., [26] documented that the circulating adiponectin level was lower in 
atrophic gastritis-positive patients than in atrophic gastritis-negative patients with no significant difference between $\mathrm{H}$. pylori-negative and $\mathrm{H}$. pyloripositive subjects.

Our work showed that hemoglobin level is not affected by the hpoadiponectinemia of the gastritis and peptic ulcer groups. Kohno K, et al., [27] found that high adiponectin level was associated with decreased levels of three erythroid-related variables (hemoglobin levels, hematocrit levels, and RBC counts). Yokota T, et al., [28] revealed that that adiponectin negatively regulates the growth of hematopoietic cells and high adiponectin levels significantly related to incidence of anemia in Japanese men. In our study, hypoadiponectinemia was not associated with change of triglyceride level but it was associated with increased cholesterol level. Qiao L [29] reported that Adiponectin affects lipid (VLDL-TG) metabolism but with unknown mechanism. Chandran et al., [30] revealed that adiponectin reduces plasma TG by increasing VLDL-TG catabolism in skeletal muscle and promotes HDL formation. Also, serum FFAs were found to be reduced in adiponectin-overexpressing mice.

In our study, as all our participants had normal renal functions with no significant correlation between renal function and adiponectin level. Iwashima et al., [31] performed a prospective study on 150 CKD patients and found an association between high level of adiponectin and worse degree of CKD. In addition, Ignacy et al., [32] found that plasma adiponectin concentrations were three times higher in End Stage Renal Disease (ESRD) patient [33] proved that adiponectin levels declined significantly after renal transplant of fifty-seven nondiabetic kidney patients.

No correlation between blood glucose level and adiponectin level detected in our study. Cnop et al., [15] concluded that adiponectin was related to insulin resistance, independent of central adiposity it is explained by sex hormones in men, but not in women. Weyer et al., [34] reported that hypoadiponectinemia has a close association with insulin resistance and hyperinsulinemia. Jiang Y, et al., [35] documented that the baseline adiponectin levels were inversely related to the risk of prediabetes despite gender and ethnic differences. Sirbu, et al., [36] proved that adiponectin mRNA in VAT was significantly higher in obese insulin-sensitive patients than in the rest of the obese patients and negatively correlated with HOMA-IR and uric acid after adjustment for gender, TG/HDL ratio and uric acid.
In the current study, there was negative correlation between the adiponectin level and peptic ulcer and gastritis. It was found that peptic ulcer and gastritis were associated with low level of adiponectin. Yamamoto, et al., [37] proved that a low serum adiponectin level was associated with an increased prevalence of endoscopic erosive gastritis in Japanese subjects. This was explained by the following physical inactivity, increased intra-abdominal pressure and impaired gastric emptying. Alkhalidy, et al., [38] proved that adiponectin had an important role in gastritis especially when there is H. pylori infection. Its level had negative correlation with BMI and lipid profile.

Kato, et al., [39] documented that hypoadiponectinaemia was associated with an increased risk of erosive esophagitis in men and might have an influence on the pathogenesis of GERD. Nigro, et al., [40] as well found that fat accumulation results in an altered expression of several hormones, growth factors, and adipokines. Adiponectin might act as a protective endocrine factor against establishment and/or progression of several obesity related diseases. Also, it represented a useful therapeutic approach against obesity and obesity-related diseases. Laurila A, et al., [41] documented that high cholesterol level and high cholesterol diet were associated with increased incidence of gastritis. The study was done on mice which were fed by high cholesterol diet and find a higher incidence of gastritis in high cholesterol fed mice than in normally fed mice.

Kim H, Jeon H, et al., [42] found that cholesterol, LDL-C and HDL-C were all decreased in DU patients with many etiological and contributing factors as dietetic, microbial and genetic that may affect the cholesterol level. H. pylori may be responsible for lipid profile alternation by inflammatory cytokines such as inerlukin-1, interlukin-6, or tumor necrotic factor, secreted by the chronic inflammatory condition induced by it. As a result, Lin C, Lia W [43] was found that statins prescribed for patients of gastritis, significantly reduces the risk of PUD as it is acting as anti-inflammatory reducing levels of C-reactive protein. Up to our knowledge, there are limited published data reveals the relation between adiponectin level and peptic ulcer.

\section{Conclusion:}

Our study revealed that a low serum adiponectin level is significantly associated with increased risk of endoscopic peptic ulcer and gastritis, after expressing other factors including age, sex, BMI, blood pressure, smoking, alcohol, lipid profile 
(cholesterol and triglycerides), FBS and endoscopic findings of peptic ulcer and gastritis.

\section{Recommendations:}

We recommend conducting large-scale studies and multicenter ones to evaluate the relation between adiponectin level and peptic ulcer. Following studies should be done on using adiponectin in the treatment of peptic ulcer and gastritis.

\section{Acknowledgements:}

We would like to thank all participants who helped during this study.

Conflict of interest: None declared.

\section{References}

1- CHUNG K.T. and SHELAT V.G.: Perforated peptic ulcer an update. World Journal of Gastrointestinal Surgery, 9 (1): 1-12. Doi:10.4240/wjgs.v9.i1.1, 2017.

2- SEPANLOU S., MALEKZADEH F., DELAVARI F., et al.: Burden of Gastrointestinal and Liver Diseases in Middle East and North Africa: Results of Global Burden of Diseases Study from 1990 to 2010. Middle East Journal of Digestive Diseases, 7 (4): 201-15, 2015.

3- BERARDI R.R. and WELAGE L.S.: Peptic ulcer disease. In: DiPiro J.T., Talbert R.L., Yee G.C., et al., eds. Pharmacotherapy: A Pathophysiologic Approach. 7 th Ed. New York, NY: McGraw-Hill, 569-87, 2008.

4- MALFERTHEINER P., CHAN F.K. and McCOLL K.E.: Peptic ulcer disease. Lancet, 374: 1449-61, 2009.

5- WANG X.X., DONG B., HONG B., et al.: Long-term prognosis in patients continuing taking antithrombotic after peptic ulcer bleeding. World Journal of Gastroenterology, 23 (4): 723-9. Doi: 10.3748/wjg.v23.i4.723, 2017.

6- OUCHI N. and WALSH K.: Adiponectin as an antiinflammatory factor. Clinical Chemical Acta; International Journal of Clinical Chemistry, 380 (1-2): 24-30, Doi: 10.1016/j.cca.2007.01.026, 2007.

7- MATSUZAWA and YUJI: "Establishment of a concept of visceral fat syndrome and discovery of adiponectin." Proceedings of the Japan Academy Series B, 86 (2): 13141, 2010.

8- PAJVANI U., DU X., COMBS T., BERG A., RAJALA M., SCHULTHESS T., ENGEL J., BROWNLEE M. and SCHERER P.: Structure-function studies of the adipocytesecreted hormone Acrp30/adiponectin. Implications for metabolic regulation and bioactivity. J. Biol. Chem., 278: 9073-85, 2003.

9- FARD A. and HAJREZAIE M.: "The Effects of Combined Adiponectin-Metformin on Glucose and Lipids Levels in Mice and Acute Toxicity and anti-ulcerogenic Activity of Adiponectin against Ethanol-Induced Gastric Mucosal Injuries in Rat" Molecular diversity, 16: 9534-52, 2011.

10- SOGABE M., OKAHISA T., KIMURA T., OKAMOTO K., MIYAMOTO H., MUGURUMA N., et al.: Influence of metabolic syndrome on upper gastrointestinal disease. Clinical Journal of Gastroenterology, 9 (4): 191-201, 2016.
11-SCHERER P.E. and TRUJILLO M.E.: Adiponectinjourney from an adipocyte secretory protein to biomarker of the metabolic syndrome. J. Intern Med., Feb., 257 (2): 167$75,2005$.

12-BOTTNER A., KRATZSCH J., MULLER G., KAPELLEN T.M., BLUHER S., KELLER E., et al.: Gender differences of adiponectin levels develop during the progression of puberty and are related to serum androgen levels. J. Clin. Endocrinol. Metab., Aug., 89 (8): 4053-61, 2004.

13- LAUGHLIN G.A.1., BARRETT-CONNOR E. and MAY S.: Sex-specific determinants of serum adiponectin in older adults: The role of endogenous sex hormones. Int. J. Obes., (Lond), Mar., 31 (3): 457-65, 2007.

14- OBATA Y., YAMADA Y., TAKAHI Y., BADEN M.Y., SAISHO K., et al.: Relationship between serum adiponectin levels and age in healthy subjects and patients with type 2 diabetes. Clin. Endocrinol. (Oxf) Aug., 79 (2): 204-10. Doi: 10.1111/cen.12041. Epub 2013 Apr. 1, 2013.

15- CNOP M., HAVEL P.J., UTZSCHNEIDER K.M., CARR D.B., SINHA M.K., et al.: Relationship of adiponectin to body fat distribution, insulin sensitivity and plasma lipoproteins: Evidence for independent roles of age and sex. Diabetologia, 46: 459-69, 2003.

16- COHEN S.S., GAMMON M.D., SIGNORELLO L.B., et al.: Serum adiponectin in relation to body mass index and other correlates in black and white women. Annals of Epidemiology, 21: 86-94, 2011.

17- COMBS T.P., BERG A.H., RAJALA M.W., KLEBANOV S., IYENGAR P., et al.: Sexual differentiation, pregnancy, calorie restriction, and aging affect the adipocyte-specific secretory protein adiponectin. Diabetes, 52: 268-76, 2003.

18- BADEN M.Y.1., YAMADA Y., TAKAHI Y., OBATA Y., SAISHO K., et al.: Association of adiponectin with blood pressure in healthy people. Clin. Endocrinol. (Oxf), Feb., 78 (2): 226-31. Doi: 10. 111 1/j. 1365-2265.2012.04370.x, 2013.

19- ADAMCZAK M., WIECEK A., FUNAHASHI T., et al.: Decreased plasma adiponectin concentration in patients with essential hypertension. American Journal of Hypertension, 16: 72-5, 2003.

20- IWASHIMA Y., KATSUYA T., ISHIKAWA K., et al.: Hypoadiponectinemia is an independent risk factor for hypertension. Hypertension, 43: 1318-23, 2004.

21- SIERKSMA A. 1., PATEL H., OUCHI N., KIHARA S., FUNAHASHI T., et al.: Effect of moderate alcohol consumption on adiponectin, tumor necrosis factor-alpha, and insulin sensitivity. Diabetes Care, Jan., 27 (1): 1849,2004

22- STEVEN BELL and ANNIE BRITTON: The Role of Alcohol Consumption in Regulating Circulating Levels of Adiponectin: A Prospective Cohort Study. J. Clin. Endocrinol. Metab., Jul., 100 (7): 2763-8, 2015.

23- JAW-SHIUN TSAI, FEI-RAN GUO, SU-CHIU CHEN, BEE-HORNG LUE, et al.: Smokers show reduced circulating adiponectin levels and adiponectin mRNA expression in peripheral blood mononuclear cells. September, Volume 218; Issue 1, Pages 168-73, 2011.

24- KOTANI K., HAZAMA A., HAGIMOTO A., et al.: Adiponectin and smoking status: A systematic review. 
Journal of atherosclerosis and thrombosis, 19: 787-94, 2012.

25- ANDO T., ISHIKAWA T., TAKAGI T., et al.: "Impact of Helicobacter pylori eradication on circulating adiponectin in humans," Helicobacter, Volume 18 (2): 158-64, 2013.

26- TORISU T., TAKATA Y., ANSAI T., et al.: Possible association of atrophic gastritis and arterial stiffness in healthy middle-aged Japanese. J. Atheroscler. Thromb., 16: 691-7, 2009.

27- KOHNO K., NARIMATSU H., SHIONO Y., et al.: High Serum Adiponectin Level Is a Risk Factor for Anemia in Japanese Men: A Prospective Observational Study of 1,029 Japanese Subjects Plos one, 11 (12): 165-11, 2016.

28- YOKOTA T., ORITANI K., TAKAHASHI I., ISHIKAWA J., MATSUYAMA A., OUCHI N., et al.: Adiponectin, a new member of the family of soluble defense collagens, negatively regulates the growth of myelomonocytic progenitors and the functions of macrophages. Blood, 96: 1723-32. PMID: 10961870, 2000.

29- QIAO L., CHENHUI ZOU, DENEYS R., WESTHUYZEN V. and SHAO J.: Adiponectin Reduces Plasma Triglyceride by Increasing VLDL Triglyceride Catabolism. Diabetes: VOl. 57, July: 1824-32, 2008.

30- CHANDRAN M., et al.: Adiponectin: More than just another fat hormone. Diabetes, 26 (8): 2442-50, 2003.

31- IWASHIMA Y., HORIO T., KUMADA M., et al.: Adiponectin and renal function, and implication as a risk of cardiovascular disease. The American Journal of Cardiology, 98 (12): 1603-8, 2006.

32- IGNACY W., CHUDEK J., ADAMCZAK M., et al : Reciprocal association of plasma adiponectin and serum C-reactive protein concentration in haemodialysis patients with end-stage kidney disease-a follow-up study. Nephron Clinical Practice, 101 (1): c18-c24, 2005.

33- IDORN T., HORNUM M., BJERRE M., et al.: Plasma adiponectin before and after kidney transplantation. Transplant International: Official Journal of the European Society for Organ Transplantation, 25 (11): 1194-203, 2012.

34- WEYER C., FUNAHASHI T., TANAKA S., et al.: "Hypoadiponectinemia in obesity and type 2 diabetes:
Close association with insulin resistance and hyperinsulinemia," Journal of Clinical Endocrinology and Metabolism, Vol. 86 (5): 1930-5, 2001.

35- JIANG Y., OWEI I., WAN J., EBENIBO S. and DAGOGO S.: Adiponectin levels predict prediabetes risk: The Pathobiology of Prediabetes in A Biracial Cohort (POP-ABC) study BMJ Open Diabetes Research and Care, 4: e000194. Doi: 10.1136/bmjdrc-2016-000194, 2016.

36- SIRBU A., BUBURUZAN L., et al.: Adiponectin expression in visceral adiposity is an important determinant of insulin resistance in morbid obesity. Endokrynologia Polska, 69 (3): 252-258, 2018.

37- YAMAMOTO S., WATABE K., ARAKI H., KAMADA Y., KATO M. and KIZU T.: Protective role of adiponectin against ethanol-induced gastric injury in mice. American Journal of Physiology-Gastrointestinal and Liver Physiology, 302 (8): 773-80, 2012.

38- AL-KHALIDY H. and HASAN R.: Role of Adiponectin in Endoscopic Gastritis. Journal of Pure and Applied Microbiology, Sept., 12 (3): 1443-1447, 2018.

39- KATO M., WATABE K., HAMASAKI T., UMEDA M. FURUBAYASHI A., KINOSHITA K., et al.: Association of low serum adiponectin levels with erosive esophagitis in men: An analysis of 2405 subjects undergoing physical check-ups. Journal of Gastroenterology, 46 (12): 13617, 2011.

40- NIGRO E., SCUDIERO O., MONACO M.L., PALMIERI A., MAZZARELLA G. and COSTAGLIOLA C.: New Insight into Adiponectin Role in Obesity and ObesityRelated Diseases. Biomed research international, article ID 658913: 14 pages, 2014.

41- LAURILA A., et al.: High-fat, high-cholesterol diet increases the incidence of gastritis in LDL receptornegative mice. Arterioscler. Thromb. Vasc. Boil., 21 (6): 991-6, 2001.

42- KIM H., JEON H., et al.: Helicobacter pylori Infection is associated with Elevated Low Density Lipoprotein Cholesterol Levels in Elderly Koreans. J. Korean Med. Sci., 26: 654-8, 2011.

43- LIN C. and LIA W.: Statin therapy is associated with reduced risk of peptic ulcer disease in the Taiwanese population. Front. Pharmacol., 8 (210): 10-33, 2017. 


\section{دراسة العلاقة بين مستوى الآديبونكتين فى البلازما وقرحة المعدة}

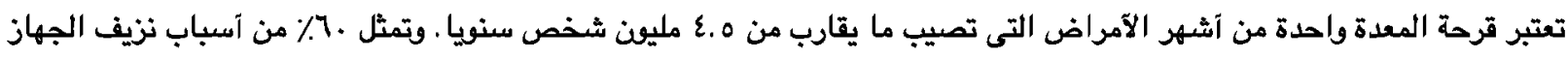

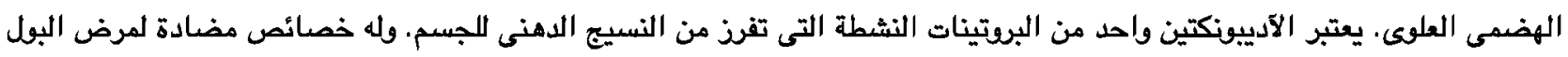
السكرى، تصلب الشرايين والإلتهابات.

الهدف من البحث: دراسة العلاقة بين مستوى الآدييونكتين في بلازما الدم وحدوث قرحة المعدة بعد تثخيصها بمنظار الجهاز الهضمى

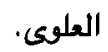

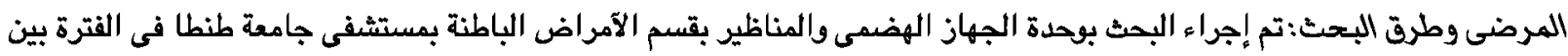

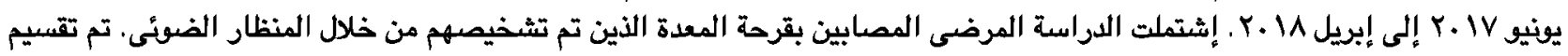

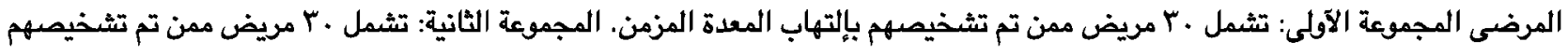

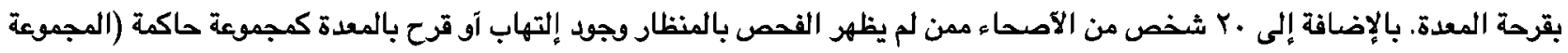
الثالة).

النتائج: آظهرت النتائج آن نقص نسبة الآديبونكتين فى بلازما الدم يرتبط بحدوث قرحة المعدة وإلتهاب المعدة والتى تم تثخيصها بمنظار

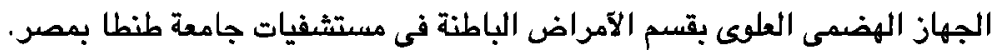

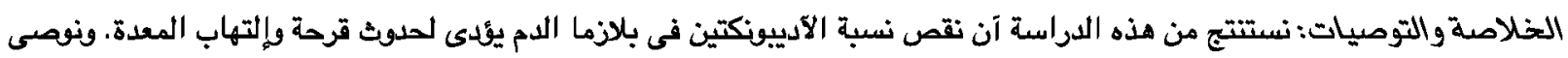

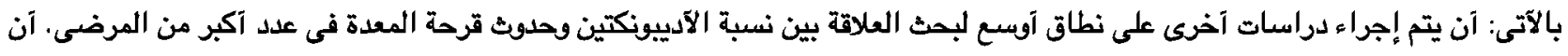
يتم دراسة إدراج الآديونكتين كمادة علاجية لمرض قرحة إنمات إلتهاب المعدة. 